\title{
Digital platforms in fashion rental: a business model analysis
}

\author{
Elisa Arrigo \\ Department of Economics, Management and Statistics (DEMS), \\ University of Milano-Bicocca, Milan, Italy
}

\begin{abstract}
Purpose - The purpose of this paper is to explore the key features of fashion rental from a business model perspective with a focus on the role played by digital platforms.

Design/methodology/approach - A qualitative research design was used based on multiple case studies of three Italian fashion rental enterprises.

Findings - The findings reveal the key aspects characterizing fashion rental business models and the centrality of digital platforms in value creation, configuration and capture activities. The study also found that fashion rental platforms are likely to exhibit further successful development in the future.

Originality/value - The academic literature on fashion rental has been mainly focussed on examining consumers' motivations and concerns, paying little attention to the enterprise's viewpoint. To date, no previous study has examined fashion rental business models from the retailer's perspective. This paper is the first to explore the key components of fashion rental business models and how digital platforms influence them from the perspective of retailers. The originality of the study is further strengthened by the unique context of analysis, namely, Italy, a leading country for global fashion.
\end{abstract}

Keywords Fashion rental, Business model, Digital platforms, Collaborative consumption, Digitalization, Fashion retailing, Sharing economy

Paper type Research paper

\section{Introduction}

Recent macro-trends, such as those of collaborative consumption (Botsman and Rogers, 2010; Möhlmann, 2015) and the sharing economy (Belk, 2014), have leveraged digital technologies to bring forward new business models (Zott et al., 2011; Chesbrough, 2010; Teece, 2010) in many industries, such as hospitality (e.g. Airbnb), transportation (e.g. ZipCar) and, more recently, fashion (e.g. Rent the Runway). In the fashion retail industry, examples of entrepreneurial initiatives that adapt the concept of sharing and collaborative consumption to the fashion context, by providing clothing and luxury reselling, renting or swapping, have raised rapidly before the emergence of coronavirus disease 2019 (COVID-19) (Adam et al., 2018; ThredUp, 2020), due to the diffusion of digital platforms (Trabucchi and Buganza, 2020).

The online fashion rental market, which involves the provision of clothes with a longer life while reducing fashion consumption, expanded exponentially in many countries (Lee and Chow, 2020). It was valued at $\$ 1,013 \mathrm{~m}$ in 2017 and was also expected to reach $\$ 1,856 \mathrm{~m}$ by 2023 (+10.6\% from 2017 to 2023) (Allied Market Research, 2019). Although the pandemic crisis will have impacted fashion rental in 2020 and 2021, from 2022 onwards it will start to increase their revenue, following the predicted recovery of the traditional apparel market and the resilience that other sharing economy markets have shown during the pandemic (Statista, 2021a; ThredUp, 2020). When compared to the size of the global clothing market (estimated to

(C) Elisa Arrigo. Published by Emerald Publishing Limited. This article is published under the Creative Commons Attribution (CC BY 4.0) licence. Anyone may reproduce, distribute, translate and create derivative works of this article (for both commercial and non-commercial purposes), subject to full attribution to the original publication and authors. The full terms of this licence may be seen at http://creativecommons.org/licences/by/4.0/legalcode

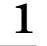

Received 17 March 2020 Revised 3 August 2020 19 October 2020

23 November 2020 18 February 2021

Accepted 27 February 2021

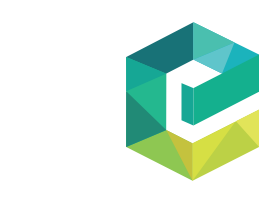

Journal of Fashion Marketing and Management: An International Vol. 26 No. 1, 2022 Emerald Publishing Limited 1361-2026 DOI 10.1108/JFMM-03-2020-0044 
JFMM 26,1

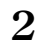

grow in value from US\$1.5tn in 2020 to about US\$2.25tn by 2025) (Statista, 2021b), fashion rental appears to characterize a very small, perhaps irrelevant, component of the entire market. However, in 2018, the US garment rental market, representing less than $1 \%$ of the total clothing market (according to GlobalData), grew 24\% compared to 5\% for the wider clothing market (Reuters, 2019). Furthermore, despite its limited size, fashion rental deserves attention especially from a sustainability point of view, with regard to reducing waste and increasing the lifespan of garments, by contrasting overconsumption and the inexorable disposal of unwanted clothing (Zhang et al., 2020). In fact, it has become clear that the fashion industry, to thrive in a sustainable future, should shift from the take-make-waste model by embracing circular economy principles and fashion rental could represent the key to a sustainable fashion industry (Braithwaite, 2018).

Notwithstanding the surge in popularity, the academic literature on fashion rental (Lee and Chow, 2020; Clube and Tennant, 2020; Mukendi and Henninger, 2020; Lang et al., 2019; Lang and Armstrong, 2018; Adam et al., 2018; Pedersen and Netter, 2015) is still limited, and even more so in terms of developing our understanding of the role played by digital platforms. This paper intends to contribute to this underdeveloped area of academic research, by exploring fashion rental from a business model perspective (Osterwalder and Pigneur, 2010; Zott et al., 2011; Chesbrough, 2010; Teece, 2010). In fact, previous academic studies have focussed mainly on consumers' motivations for participating in fashion rental systems (e.g. Clube and Tennant, 2020; Lee and Chow, 2020; Lang et al., 2020; 2019; Lang and Armstrong, 2018) and paid little attention to fashion rental from the retailer's viewpoint (Adam et al., 2018). The analysis will be concentrated on the BtoC fashion rental platforms, characterized by a company providing the platform and owning the fashion items available for rent (Iran and Schrader, 2017).

To the author's knowledge, no previous study has examined fashion rental business models from the entrepreneur/retailer's perspective. This paper is the first to contribute to bridging this gap, by adopting a multiple case study (Yin, 1994, 2017) approach with a focus on Italy, a country with a long history associated with fashion. Different textile and clothing districts characterize this long tradition in Italy (Guercini et al., 2014; Runfola and Guercini, 2013), and Italian customers are considered "luxury connoisseurs" (Kauppinen-Räisänen et al., 2018; Amatulli and Guido, 2011) with a well stratified image of luxury and fashion (Godey et al., 2013; Kapferer and Michaut, 2016).

Therefore, the research aims, firstly, to explore the key features of fashion rental business models and, secondly, to investigate the impact of digital platforms and digital technologies on their value creation, value configuration and value capture. To address these research objectives, a qualitative research design using case studies of three fashion rental enterprises based in Italy (Eisenhardt and Graebner, 2007) was carried out. The findings provide an original contribution to studies on collaborative fashion consumption and digital fashion rental, which, to date, have been researched to a limited extent but only from a customer perspective. In contrast, this paper examines fashion rental from the perspective of the strategies employed by the rental businesses themselves. Moreover, the originality of the study is further strengthened by the unique context of analysis, namely, the fashion industry in Italy.

\section{Theoretical background}

\subsection{Business model}

Despite extensive academic literature focussed on business models (Magretta, 2002; Amit and Zott, 2001; Zott et al., 2011; Chesbrough, 2010; Teece, 2010; Foss and Saebi, 2017), the business model concept remains ill-defined (George and Bock, 2011). Nevertheless, there has been a convergence in the key elements included in a business model (Wirtz et al., 2016). In its 
simplest understanding, a business model describes the design or architecture of the value creation, delivery and capture mechanisms employed by a business enterprise through its resources and capabilities to achieve a competitive advantage and survive in the long term (Teece, 2010). A business model develops in interaction with other actors (Mason and Spring, 2011) by elucidating how a company is linked to external stakeholders and engages in economic exchanges with them to create value (Zott and Amit, 2007). Thus, it explains how a value proposition is configured, a target market is identified and revenue mechanisms are defined (Chesbrough and Rosenbloom, 2002). Digitalization has had an impact on business models (Amit and Zott, 2001), both in innovative and traditional sectors, that are not usually characterized by high investment in technologies (Warner and Wager, 2019). One of the main innovations introduced by digitalization has been a lower reliance of business activities on physical elements (Caputo et al., 2021; Erevelles et al., 2016). In fact, emerging business models are increasingly based on digital infrastructures (Warner and Wager, 2019) and new forms of enterprise are developing as digital platforms that serve as a hub between buyers and sellers in the exchange of goods and services (Velu, 2015).

In this article, a business model is considered as "the rationale of how an organization creates, delivers and captures value" (Osterwalder and Pigneur, 2010, p. 14). According to Osterwalder and Pigneur (2010), the Business Model Canvas builds on nine components: customer value proposition, segments, customer relationships, channels, key resources, key activities, partners, costs and revenues. They can be conceptualized as three main aspects: how these key components create value for customers (value creation); how activities and resources are organized within the organization and throughout its supply chain and partners (value configuration) and how the company generates value (value capture) (Osterwalder et al., 2005; Bocken et al., 2014). More precisely, value creation describes how customers benefit from being served by the company (value propositions), the target customers (customer segments), and how the company establishes and develops relationships with them (customer relationships) (Osterwalder et al., 2005; Osterwalder and Pigneur, 2010). Value configuration defines how the company reaches its customers, for instance, through physical or online stores (channels), the key activities and resources used to deliver value to customers together with the partners inside the value chain. Finally, value capture refers to how revenues are generated (revenue streams), once the expenses associated with running the business model (cost structure) have been identified over time (Osterwalder and Pigneur, 2010). Especially fashion business models show relevant time dependencies since time can be considered an attribute of fashion products in terms of how old or how "timely" the items are (Guercini et al., 2014). Thus, time becomes part of the fashion offering and allows differentiation between long life cycle items (or evergreen products) and short life cycle items (able to spot trends quickly and reach the stores in the shortest possible time). Traditionally, clothing companies were used to adopting a "planned fashion model" in which the time factor was clearly divided into four seasons (Autumn/Winter and Spring/Summer). This model was based on an ability to forecast and propose fashion trends; however, over recent decades, the fashion market has become highly competitive and a constant need to "refresh" product ranges by extending the number of "seasons" has arisen (Bhardwaj and Fairhurst, 2010). New business models have emerged, including fast fashion formulae, where time management is central (Cachon, 2020; Mustonen et al., 2013; Runfola and Guercini, 2013), and the significance of time to market has increasingly impacted fashion business models.

\subsection{Collaborative fashion consumption and fashion sharing models}

Collaborative fashion consumption concerns people sharing and collaborating to meet specific needs (Camacho-Otero et al., 2019; Stål and Jansson, 2017; Pedersen and Netter, 2015). With the advent of information technology, collaborative fashion consumption forms have evolved from physical and local marketplaces to global online communities with larger economic, 
JFMM

26,1

4

environmental and social effects (Botsam and Rogers, 2010). In fact, digital platforms connect people, organizations and resources and facilitate interaction between businesses and consumers (Constantinides et al., 2018) that are useful in creating and capturing value (Parker et al., 2016), by having a disruptive impact in several markets (Trabucchi and Buganza, 2020).

To date, the majority of studies about collaborative fashion consumption investigated customers' motivations (Park and Armstrong, 2019; Camacho-Otero et al., 2019; McNeill and Venter, 2019; Iran et al., 2019; Becker-Leifhold and Iran, 2018) by showing that acceptance and/ or rejection of collaborative fashion consumption varies according to cross-cultural contexts (Iran et al., 2019). Moreover, economic and utilitarian needs, hedonistic aspects, socio-material conditions, psychosocial and cultural elements were found to be the most influential factors on customer acceptance, while hygiene and health concerns, lack of trust and information, lack of ownership and consumption habits proved to be the main barriers (Becker-Leifhold and Iran, 2018; Camacho-Otero et al., 2019). Surprisingly, the social and ethical consequences of sustainable consumption behaviour were recognised as the least likely motivators towards customer engagement with collaborative fashion consumption (McNeill and Venter, 2019).

Other studies on collaborative fashion consumption from a circular economy perspective examined whether similar business models could potentially reduce the fashion ecological footprint by extending the service life of clothes (Iran and Schrader, 2017; Zamani et al., 2017). They underlined the potential risk of problem shifting, as well as rebound, efficiency and sufficiency effects (Iran and Schrader, 2017). The environmental impact of frequent deliveries of rented clothes (and consequent transportation) (Zamani et al., 2017), and increased water and energy consumption for laundering, ironing and washing garments also needed to be taken into account in assessing the overall environmental cost.

An interesting description of collaborative fashion consumption models (Perlacia et al., 2017) differentiates between three distinct fashion sharing models based on two specific dimensions, namely the transfer of ownership (permanent vs temporary) and the role played by the firm (distributor vs broker). As a result, the three fashion sharing models of platformsharing, e-commerce and fashion rental emerged.

Platform-sharing models represent a form of re-distributed ownership, where the retailer acts as a broker making fashion items' sharing and swapping possible, and garments are temporarily used or exchanged without any monetary transaction (Park and Armstrong, 2017; Perlacia et al., 2017). For instance, in fashion libraries (Pedersen and Netter, 2015), a subscription-based service that allows customers to share wardrobes without a direct monetary exchange, revenues come from memberships and penalty fees. However, the availability of minimal human, technical and financial resources make fashion libraries' survival strictly dependent on the commitment of a small number of new entrepreneurs and the presence of a limited community of members (Pedersen and Netter, 2015). Also clothing swaps provide customers with the opportunity to extend the lifespan of their wardrobe by temporary exchanges with others, and, at the same time, find and wear something new or different (Lang and Zhang, 2019). In swapping business models, users play a dual role of customer and supplier, although a constant flow of garments cannot be guaranteed, suggesting that similar sharing models work well only on a small scale and are unlikely to become a mainstream phenomenon (Henninger et al., 2019).

In contrast, e-commerce sharing models involve transfer of ownership through the sale of second-hand or used clothing (Cervellon et al., 2012; Machado et al., 2019). However, the retailer acts only as a broker between seller and buyer without acquiring ownership of the assortment proposed online and revenues are derived mainly from commission rates for each product sold, as well as special events' tickets (Perlacia et al., 2017). Even in second-hand fashion business models, customers are contextually primary partners and suppliers and, as a consequence, retaining existing customers becomes vital for survival (Gopalakrishnan and Matthews, 2018). Nevertheless, it is less difficult than previously, when second-hand fashion was associated with being worn-out, soiled and malodorous; in fact, more recently, consumers 
have started to look at used clothes, especially luxury items, as high quality and desirable products (Zaman et al., 2019). To be more specific, customers from higher social classes were found to buy luxury second-hand items in order to satisfy their desire for exclusive and prestigious items, whereas, customers from lower social classes were mainly driven to buy second-hand clothing for financial motivations (Turunen and Leipämaa-Leskinen, 2015). A number of second-hand e-commerce platforms (and related APPs) are available worldwide and some are also operative in Italy, including the British Depop, the Spanish Micolet, the German Rebelle and the Italian Vintag, specialised in Made in Italy. Moreover, resale is expected to grow five times over the next five years (ThredUp, 2020).

In the following sub-section, fashion rental models will be explored in more detail.

\subsection{Fashion rental models}

Fashion rental is a type of access-based consumption that takes place when people use a fashion good without ownership being transferred (Lang and Armstrong, 2018; Yuan and Shen, 2019; Lang et al., 2019, 2020; Mukendi and Henninger, 2020; Iran and Schrader, 2017). WRAP, the UK's resource efficiency agency, has identified fashion rental as an innovative business model that offers clothes a longer life, while reducing the use of materials and carbon dioxide emissions. In this way, fashion rental not only fulfils an individual's fashion needs but also increases the re-use of fashion products and contributes to reducing the production of new clothes, by being eco-friendly (Lang et al., 2019).

Fashion rental can be organized either as a peer-to-peer (PtoP) or as a business-to-consumer (BtoC) platform (Iran and Schrader, 2017). In PtoP fashion rental platforms such as By Rotation or Tulerie, fashion products are exchanged directly from one consumer to another, or exchanges can be organized by a company. Instead, in BtoC platforms such as Rent the Runway or Le Tote, a company provides the platform and the products that customers can rent (Iran and Schrader, 2017). In BtoC fashion rental platforms, revenues come principally from subscription and rental fees, while expenses are mainly related to shipping costs and drycleaning services, beyond property rental and retail staff costs connected to physical stores (Perlacia et al., 2017). Moreover, the ability to develop and maintain long-term relationships together with the need to acquire knowledge and share information from external network partners is essential to their success (Adam et al., 2018). To achieve these objectives and gather and organize information from external partners, fashion rental enterprises need to leverage digital platforms to strengthen their business strategy (Yoo et al., 2012; Li et al., 2016) and develop a digital platform capability (Mikalef and Pateli, 2017; Cenamor et al., 2017, 2019).

Recent academic studies have examined customer attitudes and perceptions towards fashion rental platforms by showing that subjective norms have a greater impact than attitudes with regards to customers' intentions to engage in online fashion rental (Lee and Chow, 2020). This may depend on the novelty fashion rental embodies for most consumers, when an activity is not familiar, customers tend to collect information and rely on advice from friends to assess its potential convenience (Schepers and Wetzels, 2007). Differences were also highlighted between American and Chinese consumers on the perceived risks and enjoyment of fashion rental, as well as on attitudes towards renting (Lee and Huangh, 2020; Pantano and Stylos, 2020; Lang et al., 2019). Furthermore, by exploring the benefits and fears of customers towards fashion rental (Lang et al., 2020; Mukendi and Henninger, 2020), it was found that as customers frequently use fashion items to show their social status (Yuan and Shen, 2019), fashion rental provides them with the opportunity to have access to luxury fashion items that they could not otherwise afford. Moreover, by engaging in fashion rental, customers can experiment with multiple different styles or meet a specific dress code for a special occasion, without having to buy new items. Thus, fashion rental makes it possible to make more efficient use of personal resources such as money and space. However, customers' concerns platforms in fashion rental 
JFMM

26,1

6 about fashion rental often involved a lack of trust towards other participants, doubts about the hygiene of rented items and fears of damaging them, as well as issues related to the need to give back the chosen garment when it was felt to be yours (Mukendi and Henninger, 2020).

Despite such concerns, as noted in the introduction, the online fashion rental market has grown rapidly in the US, to the extent that famous fashion companies such as Urban Outfitters, Banana Republic and Diane von Furstenberg have entered the clothing rental subscription business (Reuters, 2019). North America represents the leading market for online fashion rental (with a market share of $40 \%$ in 2018), followed by Europe (with $27 \%$ ), especially in countries such as France, Italy and the UK, due to their high purchasing power and fashion-conscious consumers (MarketWatch, 2020). In particular, based on a survey carried out pre-pandemic COVID-19 on the propensity of Italian customers to rent clothing items instead of buying them, the Italian fashion rental market seemed to be flourishing. Approximately $80 \%$ of respondents affirmed that they would rent clothes, and $42 \%$ would rent shoes (Statista, 2019). A number of fashion rental platforms are operating in Italy and some of them are growing again after an initial huge decline during the first lockdown. Moreover, recently also the well-known Italian fashion brand Twinset launched its Pleasedontbuy platform (https:/www.pleasedontbuy.com/), whereby customers can rent capsule collections ranging in price from $€ 900$ to $€ 3,000$ over four days at a cost of between $€ 40$ and $€ 90$ in eight of its Italian mono-brand stores (Turra, 2019).

To summarize, it appears that no previous research studies have examined fashion rental business models, therefore this paper is the first designed to fill this research gap by exploring, from the perspective of retailers, the key components of fashion rental business models and how digital platforms influence them.

\section{Methodology}

Given the general lack of research on the interconnection between fashion rental and business models (Adam et al., 2018), a qualitative research design was used. By adopting a methodological approach similar to the study by Pedersen and Netter (2015), a multiple case study (Yin, 1994, 2017) was carried out. Employing a multiple case study methodology (Yin, 2013, 2017; Eisenhardt, 1989) allows the researcher to gain insights from interaction with practitioners and represents an appropriate approach to investigate and obtain managerially relevant knowledge (Gibbert et al., 2008). Case studies are particularly useful to explore situations where little is known, as is the case with fashion rental models (Eisenhardt, 1989).

In particular, multiple cases provide more reliable and testable results than single cases by increasing the generalizability of research findings (Eisenhardt, 1989; Yin, 2013) and lead to the development of new management theories (Eisenhardt and Graebner, 2007; Gummesson, 2007). Following this reasoning and driven by the scarcity of studies in the particular field of fashion rental business models, which demands more detailed methods, the multiple case study methodology was chosen as the best research method to apply.

In order to select the case studies, an initial search for Italian fashion rental enterprises was carried out via an Internet search. Additionally, by studying websites, social media pages, articles, magazines, newspapers and other secondary sources of information, it was possible to identify the main fashion rental start-ups operating in Italy. At the conclusion of these initial searches, three fashion rental enterprises were selected based on their high number of followers on Instagram and Facebook social media pages (see Table 1).

Italy was chosen as the context of analysis for two main reasons. Firstly, as argued by Iran et al. (2019), differences in collaborative fashion consumption change according to crosscultural contexts and, to date, no study on collaborative fashion consumption has been undertaken in the Italian context. Secondly, Italy is one of the most important centres of fashion and Italian customers pay great attention to fashion as "luxury connoisseurs" 
(Kauppinen-Räisänen et al., 2018; Amatulli and Guido, 2011) with a well stratified image of luxury and fashion (Godey et al., 2013; Kapferer and Michaut, 2016). Therefore, it can be argued that fashion is embedded in the Italian popular culture and carrying out an examination of fashion rental in Italy could develop our understanding of whether this form of collaborative consumption may represent a promising business model even in a country already dedicated to the notion of fashion. Moreover, selecting a single country and a single sector of analysis allowed control for variances in processes and activities that would not be feasible in cross-industry settings (Karaosman et al., 2020).

Table 1 provides a description of the fashion rental enterprises involved in the case study.

According to Yin's (2017) guidelines and previous qualitative research in the collaborative fashion consumption literature (Gopalakrishnan and Matthews, 2018; Perlacia et al., 2017; Adam et al., 2018), data were collected from multiple sources. This included secondary data concerning the target fashion rental case studies (e.g. magazines, blogs, presentations, press releases, press articles and websites); face-to-face semi-structured interviews with representatives of fashion rental platforms and direct observation of physical stores to further deepen the data gathered from the interviews.

Primary data included six one-to-one semi-structured and in-depth interviews carried out in Milan with founders and marketing/store managers of fashion rental enterprises. Given the study is exploratory, addressing a relatively novel research field that, to date, has not received significant academic attention (Pedersen and Netter, 2015), and acknowledging the novelty of fashion rental in Italy, a small sample of cases and respondents seemed appropriate to allow a deeper understanding of fashion rental business models in this setting. Moreover, semi-structured interviews provided respondents with the opportunity to tell their own story and become more active in shaping the interview process. To ensure the reliability of this study (Yin, 2013), a structured interview protocol was designed to collect and then analyse data concerning the enterprises and retailers' perspectives on the phenomenon of interest. According to similar studies (Gopalakrishnan and Matthews, 2018; Pedersen and Netter, 2015), the interview protocol was based on the Business Model Canvas framework (Osterwalder and Pigneur, 2010) which served as an analytical framework to identify and discuss similarities and differences amongst fashion rental platforms.

The interview questions (Table 2) were submitted in advance to respondents followed by face-to-face interviews.

Questions were used as a guide to generate discussion and gather information, starting with initial questions about the overall enterprise, including its foundation, activities, value propositions and target customers. Respondents were assured of personal confidentiality in order to build a connection and facilitate an honest dialogue. A second set of questions elicited detailed information on the digital technologies and online platforms' operations. Table 3 includes information about the interviewees.

Observation of and data from digital platforms were part of the data collection process together with data gathered from publicly available resources, with newspapers and magazines a key source of information. The semi-structured interviews generally lasted for

\begin{tabular}{|c|c|c|c|}
\hline Enterprises & Product category & Target customer & Physical presence \\
\hline Fashion 1 & $\begin{array}{l}\text { Fashion and luxury for every day and } \\
\text { special occasions }\end{array}$ & $\begin{array}{l}\text { Females; age } 18-55 \\
\text { years }\end{array}$ & Showroom atelier \\
\hline Fashion 2 & Luxury and fashion for special occasions & $\begin{array}{l}\text { Females; age } 35-55 \\
\text { years }\end{array}$ & $\begin{array}{l}\text { Showroom on } \\
\text { appointment }\end{array}$ \\
\hline Fashion 3 & Luxury fashion for special occasions & $\begin{array}{l}\text { Females; age } 30-40 \\
\text { years }\end{array}$ & Boutique \\
\hline
\end{tabular}

platforms in fashion rental 


\section{JFMM 26,1}

Customer segments

Value propositions

Channels

Customer

relationships

Revenue streams

Key resources

Key activities

Key partners

Table 2.

Interview questions

Cost structures
Who is your target customer?

What are the main motivations of your customers to rent fashion items?

What are the product categories and services offered to customers?

What services do you provide to customers?

What are the main channels used for reaching consumers?

What is the role of the physical contact point in your business model?

What is the role of the digital platform and social media in your business model?

How would you describe the type of relationship the customers seek to establish?

When beginning of your business did you face initial uncertainty towards fashion rental from customers?

What did you do to develop customer relationships?

What are your main sources of revenue?

Can your customers buy subscription/membership cards, if any?

What are the key resources of your business model?

What are the most important activities performed and organized?

Who are your key partners?

Who would you like to be your future key partners?

Which investments have been the most expensive?

Which activities are the most expensive?

\section{Table 3.}

Role and years of operation of interviewees

\begin{tabular}{llcc}
\hline & Role & Number of years of operation & Interview duration \\
\hline Respondent 1 & Co-founder and CEO & 5 & $1 \mathrm{~h} \mathrm{05} \mathrm{min}$ \\
Respondent 2 & Marketing Manager & 5 & $40 \mathrm{~min}$ \\
Respondent 3 & Founder and CEO & 5 & $1 \mathrm{~h}$ \\
Respondent 4 & Co-founder & 4 & $45 \mathrm{~min}$ \\
Respondent 5 & Co-founder & 4 & $50 \mathrm{~min}$ \\
Respondent 6 & Store Manager & 4 & $30 \mathrm{~min}$ \\
\hline
\end{tabular}

$45 \mathrm{~min}$ and were transcribed together with the interview notes, which generated on average seven pages of transcript for each interview, in addition to relevant parts of publicly available reports and transcripts from store visits. For the data analysis, theoretical perspectives on the Business Model Canvas were used to provide an initial coding scheme to categorize activities and processes. Within-case analysis, a process of data reduction and data management was completed to structure, define, reduce and re-assemble the data (Yin, 2013, 2017). Each of the nine key blocks comprising the Business Model Canvas was examined and then, processes and activities were categorized to understand the role of digital platforms on value creation, configuration and capture of fashion rental enterprises. Next, the business model's key features and digital practices were cross-referenced with the literature review and all aforementioned blocks were synthesised into Figure 1. Following Yin's (2017) case study guidelines, data triangulation was achieved through the use of a case study protocol, multiple sources of evidence (interviews, documents, observation during site visits) and discussion of results with fashion experts.

\section{Results}

Figure 1 contains an examination of the results of the case studies based on grouping the data collected from all sources.

Results are presented according to the nine key blocks of the Business Model Canvas (Osterwalder and Pigneur, 2010) grouped into three key sub-sections (Osterwalder et al., 2005; Bocken et al., 2014): value creation (value proposition, customer relationships and customer 


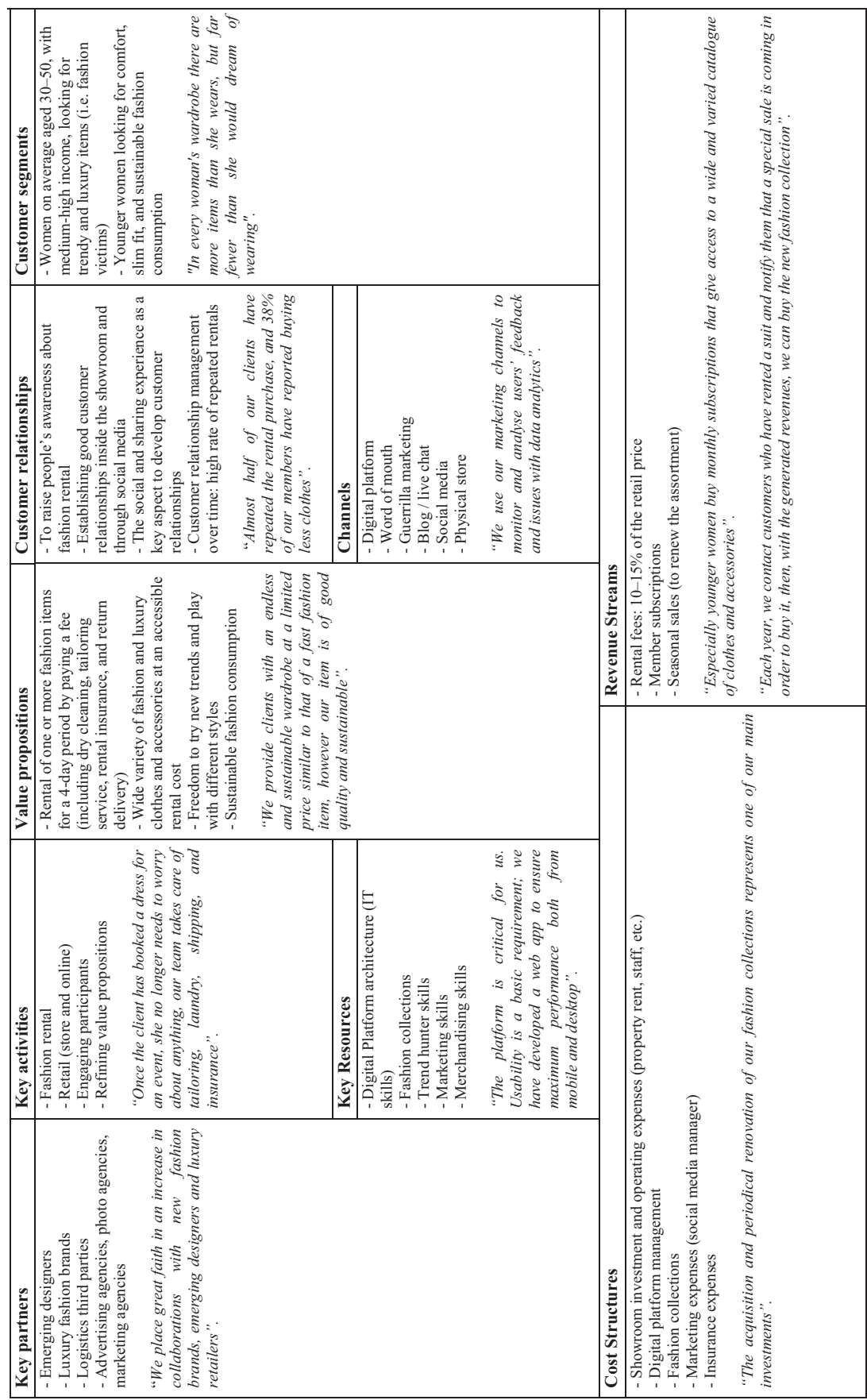

Digital platforms in fashion rental

9

Figure 1. Business model canvas-results 
JFMM 26,1 segments), value configuration (channels, key activities, key resources and key partners) and value capture (revenue streams and cost structure).

\subsection{Value creation}

The key value proposition of fashion rental enterprises refers to the opportunity for customers to rent through the enterprise's digital platform, one or more fashion items for a four-day period by paying a fee equal to approximately $10-15 \%$ of the retail price (including dry cleaning, tailoring service, rental insurance and return delivery). Fashion rental enterprises provide customers with a wide assortment of fashion and luxury items at a relatively low rental cost, the freedom to try out expensive designer pieces and play with different styles, and a fashion consumption model that is both shared and more sustainable.

The principal customer segments of the three case studies are women generally in the 3050 years age range with medium high income (\$35,000-70,000 average annual income), who look for luxury items designed by famous stylists (i.e. fashion victims), but also for comfort and slim fit for a special occasion, or for sustainable fashion consumption. The fashion rental enterprises' offer includes luxury, haute couture, fashion and accessories targeting women, with some peculiarities. In fact, the assortment proposed by Fashion 2 and 3 is composed of luxury and prestigious items of fashion brands mainly directed to women aged 35-55 years. In contrast, as well as offering luxury garments and accessories, Fashion 1 also makes available for rent ready-to-wear clothing and fashion items of emerging designers aimed at Millennials and Generation $Z$ who are more concerned about sustainability. The main motivations for Italian customers to rent a fashion item, reported by respondents, included having access to a potentially endless wardrobe at an accessible price, wearing a luxury fashion item for a special occasion and as two co-founders also noted, the desire to craft sustainable consumption. A CEO and co-founder of one of the rental enterprises stated that $38 \%$ of its clients declared they were buying fewer garments.

Concerning customer relationships, respondents stressed that fashion rental is only a recent addition to the fashion world for Italian customers used to buying clothes for personal use. Consequently, fashion rental enterprises initially needed to increase the level of fashion rental awareness amongst Italians. In fact, in Italy, suspiciousness towards fashion rental was caused because of confusion between this concept and second-hand clothing. To generate interest and word of mouth promotion amongst Italian customers, guerrilla-marketing actions were organized. Further, to counter initial confusion from customers regarding fashion rental and to strengthen customer relationships, all the founders decided to open at different periods a physical space to allow direct face-to-face contact with their customers. One fashion rental enterprise started its business online via a digital platform, as well as offline by opening a store, while the remaining two enterprises were created as purely digital platforms and only subsequently opened small showrooms. Whilst the digital platform format was chosen as the first means to develop fashion rental in Italy, following earlier successful experiences in other countries, it was also found necessary to provide Italian clients with a physical point of contact to display the key features of fashion rental. In order to attract more customers to fashion rental, two out of the three fashion rental platforms started offering customers a trial service; for a symbolic rental fee, customers could home test a selected garment and later decide whether to book it for a specific occasion. The remaining fashion rental enterprise in the case study allowed customers to rent two sizes of the same fashion garment in order to reduce the risk of ordering an incorrect size. Two platforms out of the three also showed a good rate of repeat rentals and an ability to build a solid loyal client base.

\subsection{Value configuration}

To establish good relationships with customers, the case studies highlighted how fashion rental enterprises leverage multiple channels. Obviously, the principal means is the digital 
platform that allows customers to browse fashion items, book their selection, pay the rental fee and receive the item on a fixed date. The second key marketing communication channel are social media platforms, used to publish pictures of new clothes or accessories available for rental, communicate new events and special sales with the aim of increasing the number of followers and rental service testers. Moreover, case study interviewees reported that because customers can freely express their opinions on social media or company blogs, they used these latter as a reliable source of information about the proposed collections and fashion rental activities. Data collected on social media pages (opinions, approval or disapproval) and digital platforms (final orders and desired items) have an influence on and drive the choice of future fashion collections that are acquired.

The findings showed that the key activity for all three case studies is digital fashion rental via a platform, combined with the option to buy. In fact, the case studies revealed that they periodically organize special sales where previously rented clothes are sold to clients, in this way, generating additional revenue to update the fashion assortment on the digital platform. The fashion assortment clearly constitutes a key resource for fashion rental enterprises, by being the first element of differentiation with respect to other digital platforms. One difference identified between the three case studies pertains to the procurement of collections: it was found that one enterprise buys only $1 / 3$ of its assortment, emerging designers looking to build their reputation provide free clothes that represent another $1 / 3$ of the collection and the remaining portion refers to customers' personal fashion items. In this latter case, customers that own a particular and valuable item can propose it for rent on the fashion rental platform. Then, if the item satisfactorily passes a series of checks, the fashion rental platform decides whether to propose it online and takes responsibility for managing cleaning, rental and shipping. For this service, the platform holds a percentage of the rental fee, while the rest is retained by the customer-owner. With reference to emerging designers, as they are at an early career stage, they provide the fashion rental enterprise with their collections for free in order to develop client brand awareness and test consumer acceptance, collecting useful feedback to make further improvements. Once a designer's items become popular and rent easily, the fashion rental enterprise inserts the designer as one of its providers by purchasing his/her collection for rental purposes. The other two case studies acquire the entire fashion collection at a wholesale price and, after having rented it for an entire season, then sell it to customers at varying prices depending on the condition and popularity of each item. In this way, the proposed assortment available to customers is regularly renewed and items do not go out of fashion.

Each of the fashion rental enterprises reported the digital platform as a core resource at the centre of all their rental activities directed to the web community. Accordingly, the availability and reinforcement of digital skills beyond digital marketing and merchandising represent key resources to preserve and strengthen customer relationships, often with the support of external parties.

Across the three case studies, developing external partnerships with well-established luxury brands was recognised as essential to successful growth. Having other opportunities to collaborate with luxury fashion brands would mean further leveraging their reputation, thereby enhancing the number of fashion rentals. Still a limited, although increasing, number of luxury brands collaborate with fashion rental platforms. In order to widen their market reach, fashion rental enterprises operate also in the business-to-business market, by cooperating with other businesses such as media agencies, marketing communication agencies, wedding planners and photographers that need to rent fashion items for their activities such as advertising, videos, photo shoots, etc. In this case, the digital platform represents the main channel to connect to business-to-business partners enabling fashion rental enterprises to extend their reach across the web community. 
JFMM

26,1

\subsection{Value capture}

Finally, similarities across the case studies were found to occur in the way fashion rental enterprises achieve value, particularly related to their revenue streams and cost structure. The main revenue streams stem from rental fees (starting from approximately \$44) and subscriptions with an average receipt across the three platforms at approximately $\$ 140$ per rental. All the case studies provided their clients with rental subscriptions, either limited to a specific number of fashion items or unlimited and offered different rental durations. Additional revenues came from seasonal sales of the previous collection, usually realized at the end of season, which reflects a similar approach to traditional fashion retailers. The findings showed that the three case studies' revenues increased over time and there was also evidence of an intention to further expand their rental market internationally.

Concerning cost structure, the most significant investments highlighted by the case studies referred to three elements: the creation of the digital platform architecture, setting up the showrooms, and the acquisition of fashion clothes and accessories to rent. Further additional and recurrent operational expenses are linked to the functionality and improvement of digital platforms, showrooms, staff and property rental, information technology support, clothes and accessories, and marketing expenses. Finally, other important expenses are represented by the cleaning, ironing and delivery of rented clothes. The interview data showed that, on average, each item was rented five or six times, with top performers characterized by a higher number of rentals.

\section{Discussion}

Concerning the key features of fashion rental business models, the findings identified several common patterns characterizing Italian fashion rental enterprises, although each case has its peculiarities, and therefore different business models (Runfola and Guercini, 2013) can be highlighted.

All three case studies embody BtoC fashion rental platforms (Iran and Schrader, 2017); nevertheless, specific differences have emerged pertaining to procurement mechanisms, the age of customer segments, and the range of categories (clothing, shoes, jewels, bags, etc.) available for rent on digital platforms. Specifically, it is possible to argue that Fashion 1 in part performs also a PtoP rental platform since it leases some selected luxury items owned by customers and keeps a percentage of the rental fee to remunerate the rental service.

The interviewees reported that the main barrier for customers at the launch of fashion rental platforms in Italy related to an initial lack of awareness of the concept, confusing it with second-hand clothing which was associated with being dirty and worn (Zaman et al., 2019). In acknowledging the relevance of fashion and luxury for Italian customers, as noted in previous studies (Kauppinen-Raisanen et al., 2018; Amatulli and Guido, 2011; Godey et al., 2013), the founders and CEOs participating in this study argued that a period of time was necessary to develop a fuller understanding of the new opportunities surrounding fashion rental in the Italian context. As a result, fashion rental enterprises initiated different activities such as guerrilla-marketing events to generate word of mouth, and the opening of physical points of contact with customers. Furthermore, the case studies identified specific marketing strategies aimed at lowering the risk of an unsuccessful experience for clients, such as a oneday trial formula at a reduced fee or the option of renting two sizes of the same item.

All the case studies reported a constant and growing appreciation and use of online fashion rental platforms by Italian customers and intend to further expand by entering markets in other countries. In contrast with business models characterizing fashion libraries (Pedersen and Netter, 2015) and swapping (Henninger et al., 2019) that seem to be destined to remain only small scale, and in line with online second-hand resale and peer-to-peer rental platforms that are expected to grow (ThredUp, 2020), the fashion rental platforms analysed in 
this study appear to be profitable. In fact, they show potential for future growth by leveraging the demand for sustainable fashion consumption in Italy evidenced in recent surveys (Statista, 2019; MarketWatch, 2020). In fact, the worldwide COVID-19 lockdown has caused a profound shift in how people desire to live their life, pushing customers to review their consumption practices and making them aware of the negative environmental impact of their fast fashion choices (Hagel, 2020). Obviously, in order for this to happen, enterprises should invest in additional marketing activities in Italy to raise awareness, also with the support of fashion influencers and maintain a high level of customer service.

Differently from swapping and fashion libraries (Henninger et al., 2019; Pedersen and Netter, 2015), the findings show that customers do not represent the primary partners of fashion rental enterprises since their fashion and luxury procurement is not dependent on customers and represents one of their main costs in this model. As indicated by Adam et al. (2018), to maintain long-term relationships and support further growth, fashion rental enterprises collaborate and share information with external partners. In fact, emerging designers and luxury fashion brands represent the main key partners in fashion rental business models. Early career designers will continue to look for an online window to present and test their creations to a wider public and luxury brands will continue to explore the feasibility of a partnership with fashion rental platforms as a way to facilitate item testing before buying. In cases where there has been a positive experience, wealthy customers may make an actual purchase, while customers with reduced financial means might buy previously rented luxury items during the final season sales on the fashion rental platform. In this way, fashion rental enterprises are able to provide their clients with a collection composed of evergreen luxury fashion items (with a long-life cycle) such as iconic bags, shoes or clothing and trendy fashion items (with a short life cycle) that are renewed periodically during the year through special sales designed to refresh the assortment (Bhardwaj and Fairhurst, 2010). It can be seen that in such fashion rental business models, the time factor (Guercini et al., 2014) is managed very carefully and the customer offer remains continually up-to-date and trendy.

In earlier studies (Becker-Leifhold and Iran, 2019; Camacho-Otero et al., 2019; Gopalakrishnan and Matthews, 2018; Lang et al., 2020; Mukendi and Henninger, 2020), economic aspects and functional benefits emerged as significant drivers of collaborative fashion consumption. However, in this study, the main factors reported by interviewees motivating Italian clients to rent an item from a fashion rental platform appeared to be the opportunity to wear a special dress or accessory for a particular occasion, and to access an open-ended wardrobe. In respect to past studies, this difference aligns with Iran et al. (2019) and Lang et al. (2019), who found the existence of cross-cultural differences in relation to collaborative fashion consumption. One explanation could be linked to the Made in Italy reputation and well-developed fashion culture existing amongst Italian customers who are able to assess both the quality of fashion items and those intangible aspects connoting luxury fashion brands (Kauppinen-Raisanen et al., 2018; Amatulli and Guido, 2011; Godey et al., 2013).

With regard to previous research examining collaborative fashion consumption from a circular economy perspective (Iran and Schrader, 2017; Zamani et al., 2017), the environmental savings related to fashion rental platforms appears doubtful. In fact, while in one of the fashion rental enterprises involved in this study $38 \%$ of clients reported to have reduced their acquisition of new clothes, rebound effects (Iran and Schrader, 2017) are likely to be present. Additionally, energy consumption for laundering and ironing, together with $\mathrm{CO}_{2}$ emissions linked to transportation and delivery may surpass the environmental savings associated with a reduced personal consumption of fashion items. The respondents in this study depicted fashion rental as a sustainable form of fashion consumption able to impact overconsumption and fashion waste (Zhang et al., 2020; Braithwaite, 2018). However, fashion platforms in fashion rental 
JFMM

26,1

rental may become an innovative business model capable of having a significant impact on the dominant fashion model of take-make-waste only if there is a broad shift in customer mind-sets away from ownership to access, which may be difficult to realize.

In respect to the second investigated aspect, how digital platforms and technologies influence the key components of the fashion rental business model in terms of value creation, configuration and capture, the findings show the importance of efficient management of the digital platform as a prerequisite for the fashion rental business model. Fashion rental enterprises have leveraged digital platforms to develop their rental business (Li et al., 2016) and the digital platform represents the key resource facilitating all fashion rental activities, from client browsing, to ordering to making payments, organising deliveries and transportation and providing efficient business management (Constantinides et al., 2018). Additionally, digital platforms provide a key channel to interact with customers for marketing purposes including sending personalized marketing communication, carrying out customer profiling and providing customer service. Thus, the digital platform enables all core network interactions amongst retailers, clients and partners for creating and capturing value, as argued by Parker et al. (2016) and Adam et al. (2018). Digital platforms also appear to be the central focus of innovation activities (Velu, 2015; Yoo et al., 2012) in fashion rental business models, leveraging information and data about clients (Cenamor et al., 2017) using big data analytics to acquire future collections in order to match customers' expectations. Overall, it is possible to argue that the three case studies illustrate the development of a digital platform capability (Warner and Wäger, 2019; Mikalef and Pateli, 2017), enabling the integration of critical knowledge in the pursuit of successful future growth and effective communication with external partners (Cenamor et al., 2019).

\section{Conclusions}

The purpose of this research was to provide a deeper understanding of the key features of fashion rental business models by investigating how digital platforms influence the key components of fashion rental value creation, configuration and capture. By examining three case studies of fashion rental enterprises in Italy, the findings illustrate important aspects of their business models and highlight a number of differences with respect to other models of collaborative fashion consumption (Pedersen and Netter, 2015; Henninger et al., 2019; Gopalakrishnan and Matthews, 2018). In contrast to swapping and fashion libraries that lack social acceptance and have limited potential for scalability (Henninger et al., 2019), but in line with resale and peer-to-peer platforms that are expected to grow worldwide (ThredUp, 2020), BtoC fashion rental platforms are likely to continue to expand further even in Italy where customers are fashion and luxury connoisseurs (Kauppinen-Räisänen et al., 2018; Amatulli and Guido, 2011; Godey et al., 2013; Kapferer and Michaut, 2016).

The study has several theoretical implications for the current academic literature. Firstly, although previous studies on collaborative fashion consumption literature (Camacho-Otero et al., 2019; Iran et al., 2019; Becker-Leifhold and Iran, 2018; Gopalakrishnan and Matthews, 2018; Henninger et al., 2019) and fashion rental (Lee and Chow, 2020; Lang et al., 2020; Lang and Armstrong, 2018; Mukendi and Henninger, 2020) explored customer motivations and concerns, research adopting a business perspective appears to be almost absent (Pedersen and Netter, 2015; Adam et al., 2018). This study offers the first attempt to understand fashion rental business models identifying the key aspects of similarity and dissimilarity with other forms of collaborative consumption explored in earlier studies, while highlighting the key role played by digital platforms. Secondly, the findings also contribute to the existing research field on digitalization and business models (Caputo et al., 2021; Warner and Wager, 2019; Velu, 2015; Ervelles et al., 2016), illustrating how fashion rental platforms represent an emerging form or archetype of business models developed as a result of digitalization. This 
contribution is further strengthened by the fact that this new archetype has evolved in the fashion industry, a sector traditionally characterized by limited technological investment (Warner and Wager, 2019), which has only recently begun to embrace digital transformation.

Furthermore, the study has managerial implications for fashion marketing practitioners, as new start-ups may learn from the activities highlighted in the three case studies, prior to entering the fashion rental market and launching their own digital rental platforms. The findings also underline many important elements for implementing a successful business

model such as the use of digital technologies and the creation of partnerships with external parties to support enterprises in creating a new venture without needing a large financial investment. Moreover, there may be managerial implications for established luxury fashion brands interested in collaborating with fashion rental platforms to make their collections available to customers. Fashion rental platforms could provide clients with a "test before buy" option, with the aim of countering the high return rate typical of e-commerce purchases, as well as offering luxury brands an opportunity to reach out to their increasingly digital community for marketing purposes. Luxury fashion managers could decide to embrace digital fashion rental, following the example of Twinset, Urban Outfitters and Banana Republic, in order to widen their market by accessing customers unable to afford the purchase of a luxury item. Finally, luxury fashion brands could partner with fashion rental enterprises by adopting a revenue-sharing model, whereby the luxury fashion brand proposes items for lease on the digital platform, taking care of cleaning and delivery costs, and the fashion rental platform retains a portion of the generated revenue.

To conclude, one of the main limitations of this study is that the empirical evidence was restricted to three case studies. However, acknowledging the novelty of fashion rental in Italy and the limited number of Italian fashion rental enterprises, a small sample seemed appropriate to allow a deeper understanding of fashion rental business models in this context. As new fashion rental platforms are launched in the future, further studies could be undertaken to support these preliminary findings. Another limitation is the focus on BtoC fashion rental platforms (Iran and Schrader, 2017); therefore, future studies could also explore peer-to-peer fashion rental business models and compare them with these findings. To date, no existing study has carried out a cross-cultural analysis of collaborative fashion consumption (Lang et al., 2019; Iran et al., 2019) in Italy. Therefore, the focus of future research could involve carrying out empirical studies on Italian customers of fashion rental platforms. Finally, the environmental impact of fashion rental platforms deserves deeper examination to understand if fashion rental could contribute towards reducing fashion's ecological footprint.

\section{References}

Adam, M., Strähle, J. and Freise, M. (2018), "Dynamic capabilities of early-stage firms: exploring the business of renting fashion”, Journal of Small Business Strategy, Vol. 28 No. 2, pp. 49-67.

Allied Market Research (2019), "Online clothing rental market overview", available at: https:/www. alliedmarketresearch.com/online-clothing-rental-market.

Amatulli, C. and Guido, G. (2011), "Determinants of purchasing intention for fashion luxury goods in the Italian market", Journal of Fashion Marketing and Management: An International Journal, Vol. 15 No. 1, pp. 123-136.

Amit, R. and Zott, C. (2001), "Value creation in e-business", Strategic Management Journal, Vol. 22 Nos 6-7, pp. 493-520.

Becker-Leifhold, C. and Iran, S. (2018), "Collaborative fashion consumption-drivers, barriers and future pathways", Journal of Fashion Marketing and Management: An International Journal, Vol. 22 No. 2, pp. 189-208.

Belk, R. (2014), "You are what you can access: sharing and collaborative consumption online", Journal of Business Research, Vol. 67 No. 8, pp. 1595-1600. 
JFMM 26,1

Bhardwaj, V. and Fairhurst, A. (2010), "Fast fashion: response to changes in the fashion industry", The International Review of Retail, Distribution and Consumer Research, Vol. 20 No. 1, pp. 165-173.

Bocken, N.M., Short, S.W., Rana, P. and Evans, S. (2014), "A literature and practice review to develop sustainable business model archetypes", Journal of Cleaner Production, Vol. 65, pp. 42-56.

Botsman, R. and Rogers, R. (2010), "Beyond zipcar: collaborative consumption", Harvard Business Review, Vol. 88 No. 10, p. 30.

Braithwaite, N. (2018), "Clothing rental could be the key to a stylishly sustainable fashion industry", The Conversation, July 31, 2018, available at: https://theconversation.com/clothing-rental-couldbe-the-key-to-a-stylishly-sustainable-fashion-industry-100106 (accessed 19 September 2020).

Cachon, G.P. (2020), "A research framework for business models: what is common among fast fashion, e-tailing, and ride sharing?", Management Science, Vol. 66 No. 3, pp. 1172-1192.

Camacho-Otero, J., Boks, C. and Pettersen, I.N. (2019), "User acceptance and adoption of circular offerings in the fashion sector: insights from user-generated online reviews", Journal of Cleaner Production, Vol. 231, pp. 928-939.

Caputo, A., Pizzi, S., Pellegrini, M.M. and Dabić, M. (2021), "Digitalization and business models: where are we going? A science map of the field", Journal of Business Research, Vol. 123, pp. 489-501.

Cenamor, J., Sjödin, D.R. and Parida, V. (2017), "Adopting a platform approach in servitization: leveraging the value of digitalization", International Journal of Production Economics, Vol. 192, pp. 54-65.

Cenamor, J., Parida, V. and Wincent, J. (2019), "How entrepreneurial SMEs compete through digital platforms: the roles of digital platform capability, network capability and ambidexterity", Journal of Business Research, Vol. 100, pp. 196-206.

Cervellon, M., Carey, L. and Harms, T. (2012), "Something old, something used: determinants of women's purchase of vintage fashion vs second-hand fashion", International Journal of Retail and Distribution Management, Vol. 40 No. 12, pp. 956-974.

Chesbrough, H. (2010), "Business model innovation: opportunities and barriers", Long Range Planning, Vol. 43 Nos 2-3, pp. 354-363.

Chesbrough, H. and Rosenbloom, R.S. (2002), "The role of the business model in capturing value from innovation: evidence from Xerox Corporation's technology spin-off companies", Industrial and Corporate Change, Vol. 11 No. 3, pp. 529-555.

Clube, R.K. and Tennant, M. (2020), "Exploring garment rental as a sustainable business model in the fashion industry: does contamination impact the consumption experience?", Journal of Consumer Behaviour, Vol. 19 No. 4, pp. 359-370.

Constantinides, P., Henfridsson, O. and Parker, G.G. (2018), "Introduction-platforms and infrastructures in the digital age", Information Systems Research, Vol. 29 No. 2, pp. 381-400.

Eisenhardt, K.M. (1989), "Building theories from case study research", Academy of Management Review, Vol. 14 No. 4, pp. 532-550.

Eisenhardt, K.M. and Graebner, M.E. (2007), "Theory building from cases: opportunities and challenges", Academy of Management Journal, Vol. 50 No. 1, pp. 25-32.

Erevelles, S., Fukawa, N. and Swayne, L. (2016), "Big Data consumer analytics and the transformation of marketing", Journal of Business Research, Vol. 69 No. 2, pp. 897-904.

Foss, N.J. and Saebi, T. (2017), "Fifteen years of research on business model innovation: how far have we come, and where should we go?”, Journal of Management, Vol. 43 No. 1, pp. 200-227.

George, G. and Bock, A.J. (2011), "The business model in practice and its implications for entrepreneurship research", Entrepreneurship Theory and Practice, Vol. 35 No. 1, pp. 83-111.

Gibbert, M., Ruigrok, W. and Wicki, B. (2008), “What passes as a rigorous case study?", Strategic Management Journal, Vol. 29 No. 13, pp. 1465-1474. 
Godey, B., Pederzoli, D., Aiello, G., Donvito, R., Wiedmann, K.P. and Hennigs, N. (2013), "A crosscultural exploratory content analysis of the perception of luxury from six countries", The Journal of Product and Brand Management, Vol. 22 No. 3, pp. 229-237.

Gopalakrishnan, S. and Matthews, D. (2018), "Collaborative consumption: a business model analysis of second-hand fashion", Journal of Fashion Marketing and Management: An International Journal, Vol. 22 No. 3, pp. 354-368.

Guercini, S., Ranfagni, S. and Runfola, A. (2014), "Time in business-to-business interactions. A case analysis in textile and clothing", Journal of Global Fashion Marketing, Vol. 5 No. 1, pp. 87-102.

Gummesson, E. (2007), “Access to reality: observations on observational methods”, Qualitative Market Research: An International Journal, Vol. 10 No. 2, pp. 130-134.

Hagel, M. (2020), "Has Covid-19 brought an end to clothing rental?", available at: https://www.fashionnorth.com/2020/12/04/has-covid-19-brought-an-end-to-clothing-renta1/.

Henninger, C.E., Bürklin, N. and Niinimäki, K. (2019), "The clothes swapping phenomenon-when consumers become suppliers", Journal of Fashion Marketing and Management: An International Journal, Vol. 23 No. 3, pp. 327-344.

Iran, S. and Schrader, U. (2017), "Collaborative fashion consumption and its environmental effects", Journal of Fashion Marketing and Management: An International Journal, Vol. 21 No. 4, pp. 468-482.

Iran, S., Geiger, S.M. and Schrader, U. (2019), "Collaborative fashion consumption-A cross-cultural study between Tehran and Berlin", Journal of Cleaner Production, Vol. 212, pp. 313-323.

Kapferer, J.N. and Michaut, A. (2016), "Pursuing the Concept of Luxury: a cross-country comparison and segmentation of luxury buyers' perception of luxury", Journal of International Marketing Strategy, Vol. 4 No. 1, pp. 6-23.

Karaosman, H., Perry, P., Brun, A. and Morales-Alonso, G. (2020), "Behind the runway: extending sustainability in luxury fashion supply chains", Journal of Business Research, Vol. 117, pp. 652-663.

Kauppinen-Räisänen, H., Björk, P., Lönnström, A. and Jauffret, M.N. (2018), "How consumers' need for uniqueness, self-monitoring, and social identity affect their choices when luxury brands visually shout versus whisper", Journal of Business Research, Vol. 84, pp. 72-81.

Lang, C. and Armstrong, C.M.J. (2018), "Collaborative consumption: the influence of fashion leadership, need for uniqueness, and materialism on female consumers' adoption of clothing renting and swapping", Sustainable Production and Consumption, Vol. 13, pp. 37-47.

Lang, C. and Zhang, R. (2019), "Second-hand clothing acquisition: the motivations and barriers to clothing swaps for Chinese consumers", Sustainable Production and Consumption, Vol. 18, pp. 156-164.

Lang, C., Li, M. and Zhao, L. (2020), "Understanding consumers' online fashion renting experiences: a text-mining approach", Sustainable Production and Consumption, Vol. 21, pp. 132-144.

Lang, C., Seo, S. and Liu, C. (2019), "Motivations and obstacles for fashion renting: a cross-cultural comparison", Journal of Fashion Marketing and Management: An International Journal, Vol. 23 No. 4, pp. 519-536.

Lee, S.H. and Chow, P.S. (2020), "Investigating consumer attitudes and intentions toward online fashion renting retailing", Journal of Retailing and Consumer Services, Vol. 52, p. 101892.

Lee, S.H. and Huang, R. (2020), "Consumer responses to online fashion renting: exploring the role of cultural differences", International Journal of Retail and Distribution Management, Vol. 49 No. 2, pp. 187-203.

Li, W., Liu, K., Belitski, M., Ghobadian, A. and O’Regan, N. (2016), “e-Leadership through strategic alignment: an empirical study of small-and medium-sized enterprises in the digital age", Journal of Information Technology, Vol. 31 No. 2, pp. 185-206.

platforms in fashion rental 
JFMM 26,1

Machado, M.A.D., de Almeida, S.O., Bollick, L.C. and Bragagnolo, G. (2019), "Second-hand fashion market: consumer role in circular economy", Journal of Fashion Marketing and Management: An International Journal, Vol. 23 No. 3, pp. 382-395.

Magretta, J. (2002), "Why business models matter", Harvard Business Review, Vol. 80 No. 5, pp. 86-92.

MarketWatch (2020), "Online clothing rental market 2020 industry research, share, trend, global industry size, price, future analysis, regional outlook to 2025", available at: https://www. marketwatch.com/press-release/online-clothing-rental-market-2020-industry-research-sharetrend-global-industry-size-price-future-analysis-regional-outlook-to-2025-2020-04-30.

Mason, K. and Spring, M. (2011), "The sites and practices of business models", Industrial Marketing Management, Vol. 40 No. 6, pp. 1032-1041.

McNeill, L. and Venter, B. (2019), "Identity, self-concept and young women's engagement with collaborative, sustainable fashion consumption models", International Journal of Consumer Studies, Vol. 43 No. 4, pp. 368-378.

Mikalef, P. and Pateli, A. (2017), "Information technology-enabled dynamic capabilities and their indirect effect on competitive performance: findings from PLS-SEM and fsQCA", Journal of Business Research, Vol. 70, pp. 1-16.

Möhlmann, M. (2015), "Collaborative consumption: determinants of satisfaction and the likelihood of using a sharing economy option again", Journal of Consumer Behaviour, Vol. 14 No. 3, pp. 193-207.

Mukendi, A. and Henninger, C.E. (2020), "Exploring the spectrum of fashion rental", Journal of Fashion Marketing and Management: An International Journal, Vol. 24 No. 3, pp. 455-469.

Mustonen, M., Pal, R., Mattila, H. and Mashkoor, Y. (2013), "Success indicators in various fashion business models", Journal of Global Fashion Marketing, Vol. 4 No. 2, pp. 74-92.

Osterwalder, A. and Pigneur, Y. (2010), Business Model Generation: A Handbook for Visionaries, Game Changers, and Challengers, John Wiley and Sons, Hoboken, New Jersey.

Osterwalder, A., Pigneur, Y. and Tucci, C.L. (2005), "Clarifying business models: origins, present, and future of the concept", Communications of the Association for Information Systems, Vol. 16 No. 1 , p. 1.

Pantano, E. and Stylos, N. (2020), "The Cinderella moment: exploring consumers' motivations to engage with renting as collaborative luxury consumption mode", Psychology and Marketing, Vol. 37 No. 5, pp. 740-753.

Park, H. and Armstrong, C.M.J. (2017), "Collaborative apparel consumption in the digital sharing economy: an agenda for academic inquiry", International Journal of Consumer Studies, Vol. 41 No. 5, pp. 465-474.

Park, H. and Armstrong, C.M.J. (2019), "Is money the biggest driver? Uncovering motives for engaging in online collaborative consumption retail models for apparel", Journal of Retailing and Consumer Services, Vol. 51, pp. 42-50.

Parker, G.G., Van Alstyne, M.W. and Choudary, S.P. (2016), Platform Revolution: How Networked Markets Are Transforming the Economy and How to Make Them Work for You, WW Norton and Company, New York.

Pedersen, E.R.G. and Netter, S. (2015), "Collaborative consumption: business model opportunities and barriers for fashion libraries", Journal of Fashion Marketing and Management, Vol. 19 No. 3, pp. 258-273.

Perlacia, A., Duml, V. and Saebi, T. (2017), “Collaborative consumption: live fashion, don't own itdeveloping new business models for the fashion industry", Beta, Vol. 1, pp. 1-24.

Reuters (2019), "Rental apparel brings new wrinkles for retail stores", available at: https://www. businessoffashion.com/articles/news-analysis/rental-apparel-brings-new-wrinkles-for-retailstores/ (accessed 18 September 2019). 
Runfola, A. and Guercini, S. (2013), "Fast fashion companies coping with internationalization: driving the change or changing the model?", Journal of Fashion Marketing and Management: An International Journal, Vol. 17 No. 2, pp. 190-205.

Schepers, J. and Wetzels, M. (2007), "A meta-analysis of the technology acceptance model: investigating subjective norm and moderation effects", Information and Management, Vol. 44 No. 1, pp. 90-103.

Stål, H.I. and Jansson, J. (2017), "Sustainable consumption and value propositions: exploring productservice system practices among Swedish fashion firms", Sustainable Development, Vol. 25 No. 6 , pp. 546-558.

Statista (2019), "Sustainable fashion consumption in Italy", available at: https://www.statista.com/ statistics/1049515/most-interesting-clothing-items-to-rent-in-italy/.

Statista (2021a), "Power driven hand tools", available at: https://www.statista.com/study/78882/powerdriven-hand-tools-in-the-sharing-economy/.

Statista (2021b), "Global apparel market", available at: https://www.statista.com/topics/5091/apparelmarket-worldwide/.

Teece, D.J. (2010), "Business models, business strategy and innovation”, Long Range Planning, Vol. 43 Nos 2-3, pp. 172-194.

ThredUp (2020), "Resale report", available at: http://www.thredup.com/.

Trabucchi, D. and Buganza, T. (2020), "The power of two-sided platforms to disseminate resistant innovations", Management Decision, Vol. 59 No. 13, pp. 1-14.

Turra, A. (2019), "Twinset to introduce clothing rental program during milan fashion week", available at: https://wwd.com/fashion-news/designer-luxury/twinset-to-introduce-clothing-rentalprogram-during-milan-fashion-week-1203223106/.

Turunen, L.L.M. and Leipämaa-Leskinen, H. (2015), "Pre-loved luxury: identifying the meanings of second-hand luxury possessions", The Journal of Product and Brand Management, Vol. 24 No. 1 , pp. 57-65.

Velu, C. (2015), "Business model innovation and third-party alliance on the survival of new firms", Technovation, Vol. 35, pp. 1-11.

Warner, K.S. and Wäger, M. (2019), "Building dynamic capabilities for digital transformation: an ongoing process of strategic renewal”, Long Range Planning, Vol. 52 No. 3, pp. 326-349.

Wirtz, B.W., Pistoia, A., Ullrich, S. and Göttel, V. (2016), "Business models: origin, development and future research perspectives", Long Range Planning, Vol. 49 No. 1, pp. 36-54.

Yin, R.K. (1994), "Discovering the future of the case study. Method in evaluation research", Evaluation Practice, Vol. 15 No. 3, pp. 283-290.

Yin, R.K. (2013), "Validity and generalization in future case study evaluations", Evaluation, Vol. 19 No. 3, pp. 321-332.

Yin, R.K. (2017), Case Study Research and Applications: Design and Methods, Sage Publications, Thousand Oaks, California.

Yoo, Y., Boland, R.J. Jr, Lyytinen, K. and Majchrzak, A. (2012), "Organizing for innovation in the digitized world", Organization Science, Vol. 23 No. 5, pp. 1398-1408.

Yuan, Q. and Shen, B. (2019), "Renting fashion with strategic customers in the sharing economy", International Journal of Production Economics, Vol. 218, pp. 185-195.

Zaman, M., Park, H., Kim, Y.K. and Park, S.H. (2019), "Consumer orientations of second-hand clothing shoppers”, Journal of Global Fashion Marketing, Vol. 10 No. 2, pp. 163-176.

Zamani, B., Sandin, G. and Peters, G.M. (2017), "Life cycle assessment of clothing libraries: can collaborative consumption reduce the environmental impact of fast fashion?", Journal of Cleaner Production, Vol. 162, pp. 1368-1375.

platforms in fashion rental 
JFMM

26,1

20

Zhang, L., Wu, T., Liu, S., Jiang, S., Wu, H. and Yang, J. (2020), "Consumers' clothing disposal behaviours in Nanjing, China", Journal of Cleaner Production, Vol. 276, p. 123184.

Zott, C. and Amit, R. (2007), "Business model design and the performance of entrepreneurial firms", Organization Science, Vol. 18 No. 2, pp. 181-199.

Zott, C., Amit, R. and Massa, L. (2011), "The business model: recent developments and future research”, Journal of Management, Vol. 37 No. 4, pp. 1019-1042.

\section{About the author}

Elisa Arrigo, PhD, is Associate Professor of Marketing at the University of Milano-Bicocca, Department of Economics, Management and Statistics (DEMS), Milan (Italy). She holds a PhD in Marketing and Business Management and during her $\mathrm{PhD}$ studies; she was a visiting scholar at the Stockholm School of Business (Sweden) and London Business School (UK). She teaches Global Marketing, Marketing and Marketing Metrics at Milano-Bicocca University. Her main expertise and research interests are in the field of global marketing with particular reference to luxury and fashion brands and she is also engaged in international research projects pertaining these topics. Her work has been featured in several peer-to-peer journals such as Journal of Fashion Marketing and Management, Journal of Retailing and Consumer Services, Journal of Retail and Distribution Management, Management Research Review and Business Process Management Journal. She authored also two books. Elisa Arrigo can be contacted at: elisa.arrigo@unimib.it

For instructions on how to order reprints of this article, please visit our website:

www.emeraldgrouppublishing.com/licensing/reprints.htm

Or contact us for further details: permissions@emeraldinsight.com 